\section{(6) OPEN ACCESS}

\title{
Incidence, risk factors and severity of retinopathy of prematurity in Turkey (TR-ROP study): a prospective, multicentre study in 69 neonatal intensive care units
}

\author{
Ahmet Yagmur Bas, ${ }^{1}$ Nihal Demirel, ${ }^{1}$ Esin Koc, ${ }^{2}$ Dilek Ulubas Isik, ${ }^{3}$ \\ ibrahim Murat Hirfanoglu, ${ }^{2}$ Turan Tunc, ${ }^{4}$ on behalf of the TR-ROP Study Group
}

\begin{abstract}
${ }^{1}$ Department of Neonatology, Yildirim Beyazit University Faculty of Medicine, Ankara, Turkey

${ }^{2}$ Department of Neonatology, Gazi University Faculty of Medicine, Ankara, Turkey ${ }^{3}$ Department of Neonatology, Etlik Zubeyde Hanim Women's Health Teaching and Research Hospital, University of Health Sciences, Ankara, Turkey ${ }^{4}$ Neonatology Division, Memorial Hospital, Istanbul, Turkey
\end{abstract}

Correspondence to Professor Ahmet Yagmur Bas, Department of Neonatology, Etlik Zubeyde Hanim Women's Health Teaching and Research Hospital, Ankara 06010, Turkey; yagmur32@yahoo.com

Received 22 December 2017 Revised 23 January 2018 Accepted 16 February 2018 Published Online First 8 March 2018

\begin{abstract}
Background To evaluate the prevalence, risk factors and treatment of retinopathy of prematurity (ROP) in Turkey and to establish screening criteria for this condition.

Methods A prospective cohort study (TR-ROP) was
\end{abstract} performed between 1 April 2016 and 30 April 2017 in 69 neonatal intensive care units (NICUs). Infants with a birth weight $(B W) \leq 1500 \mathrm{~g}$ or gestational age $(G A) \leq 32$ weeks and those with a BW>1500 g or GA>32 weeks with an unstable clinical course were included in the study. Predictors for the development of ROP were determined by logistic regression analyses.

Results The TR-ROP study included 6115 infants: 4964 $(81 \%)$ with a GA $\leq 32$ weeks and 1151 (19\%) with a GA>32 weeks. Overall, $27 \%$ had any stage of ROP and $6.7 \%$ had severe ROP. A lower BW, smaller GA, total days on oxygen, late-onset sepsis, frequency of red blood cell transfusions and relative weight gain were identified as independent risk factors for severe ROP in infants with a BW $\leq 1500 \mathrm{~g}$. Of all infants, 414 needed treatment and $395(95.4 \%)$ of the treated infants had a BW $\leq 1500 \mathrm{~g}$.

Sixty-six (16\%) of the treated infants did not fulfil the Early Treatment for Retinopathy of Prematurity requirements for treatment.

Conclusions Screening of infants with a GA $\leq 34$ weeks or a $B W<1700 \mathrm{~g}$ appears to be appropriate in Turkey. Monitoring standards of neonatal care and conducting quality improvement projects across the country are recommended to improve neonatal outcomes in Turkish NICUs.

Trial registration number NCT02814929, Results.

\section{INTRODUCTION}

Retinopathy of prematurity (ROP), a vasoproliferative disorder of the immature retina in premature infants, is a significant cause of blindness in many middle-income countries. The prevalence of ROP is lower in high-income countries, where risk factors such as oxygen administration and blood oxygen saturation are strictly monitored. ${ }^{1}$ Severe ROP is typically found in infants with a very low gestational age (GA) at birth in developed countries. ${ }^{12}$ Heavier and more mature babies can also develop ROP in developing countries, because there is insufficient awareness of the risk factors of the disease process, a shortage of skilled professionals and/or a shortage of essential equipment to care for infants. ${ }^{3}$

In recent years, Turkey has been developing programmes to improve neonatal health. This study
(TR-ROP) determined the prevalence and treatment modalities of infants with ROP in Turkey and was the first multicentre study to analyse risk factors for ROP development in the country. Based on data obtained from infants, criteria for ROP screening in Turkey were evaluated. Because Turkey has received many refugees in recent years, this study also evaluated the prevalence of ROP in preterm infants born to refugees.

\section{METHODS}

The TR-ROP study was promoted by the Turkish Neonatology Society and included preterm infants screened for ROP between 1 April 2016 and 30 April 2017. In Turkey, the total number of neonatal intensive care units (NICUs) including neonatologists on the medical staff is 134 (22 private, 40 university and 72 state hospitals). In total, 69 NICUs (8 private, 39 university and 22 state hospitals) agreed to take part in the study (51\% of all). Heads of the NICUs and directors of hospitals gave written consent to participate in the research. It was approved by the ethics committee and informed consent was obtained from the parents before the initial screening.

\section{Study population}

This prospective cohort study evaluated the incidence and severity of ROP in relation to GA, birth weight (BW) and treatment modalities. The independent risk factors for the development of severe ROP in infants with a BW $\leq 1500 \mathrm{~g}$ and for any ROP in infants with a BW $>1500 \mathrm{~g}$ were assessed.

Infants with a $\mathrm{BW} \leq 1500 \mathrm{~g}$ or $\mathrm{GA} \leq 32$ weeks and those with a BW $>1500 \mathrm{~g}$ or GA $>32$ weeks, who were determined by the attending clinician to be at risk for ROP development, were screened. Then the medical records of retinal examinations of preterm infants who met the screening criteria were evaluated. The data on refugee infants were also recorded. Examinations took place in the NICU or outpatient facility (for discharged infants). Eligible infants who were discharged before the first screening and missed or did not complete all screening sessions were excluded from the study. The data are restricted to all babies who underwent all the screening sessions. Infants with congenital anomalies, chromosomal abnormalities and 
those who died before the first ophthalmic examination were excluded from the study.

\section{Dataset}

Neonatologists who agreed to participate in this study provided data regarding ROP in their NICUs. A case report form (CRF) for each enrolled patient was completed by the participating neonatologist. Data were collected through an online data entry system via a special network named the 'Trials-Network'. All the questions in the CRF were required to be answered. The data entry system did not allow the collaborator to proceed and submit the data if no response was received for any question in the CRF. Anonymous data were entered into password protected database to maintain confidentiality. The records from 69 NICUs were pooled together and analysed at the end of the study.

\section{Clinical characteristics}

Antenatal, natal and postnatal risk factors for the development of ROP including maternal age, use of antenatal corticosteroids, preeclampsia/eclampsia, infants of diabetic mothers, chorioamnionitis (clinical or histopathological), in vitro fertilisation, multiple births, mode of delivery, sex, GA, BW, small for gestational age (SGA; 10th percentile), ${ }^{4}$ resuscitation in the delivery room, respiratory distress syndrome (RDS), surfactant treatment, duration of invasive/noninvasive mechanical ventilation and oxygen therapy, intracranial haemorrhage $>$ Grade II according to Papile staging, ${ }^{5}$ haemodynamically significant patent ductus arteriosus (PDA), early/late neonatal sepsis (clinically proven or culture positive), necrotising enterocolitis (NEC) $\geq$ Stage II in accordance with the modified Bell criteria, ${ }^{6}$ the number of red blood cell (RBC) transfusions (15 mL/kg for each transfusion), bronchopulmonary dysplasia (BPD), oxygen requirement at 36 weeks postmenstrual age, relative weight gain and breastfeeding were recorded on the CRF for each patient.

\section{Ophthalmic examinations}

The International Classification of ROP guidelines were used to record the stage of the disorder, location by zone and signs of plus disease. ${ }^{7}$ All infants meeting the screening criteria were scheduled to have their first examination at between 4 and 6 weeks of life. Ophthalmic examinations were continued until full retinal vascularisation and the maximum stage of ROP for each infant was reported. The data were analysed for the most advanced stage of ROP in the eye with the most severe disease.

Severe ROP was defined as ROP needing treatment. Criteria for treatment of ROP were based on the Early Treatment for Retinopathy of Prematurity (ETROP) $;^{8}$ however, not all treated patients met this criteria and were defined as the 'unclassified' group. The study also investigated the need for laser photocoagulation, intravitreal bevacizumab (IVB) and vitreoretinal surgery for ROP.

The NICUs having no treatment options transferred the infants to other facilities where ROP treatment is available. The referring neonatologists completed the CRF forms for these patients after being in contact with the receiving facilities.

\section{Statistical analyses}

Statistical analyses were conducted using SPSS statistical software for Windows, V.21.0 (SPSS, Chicago, Illinois, USA). The results are presented as numbers (n), frequencies (\%), means with the respective SDs and medians with their IQRs. Parametric tests were used to analyse variables. The $\chi^{2}$ test was used to compare categorical variables. A two-tailed value of $\mathrm{p} \leq 0.05$

\begin{tabular}{|c|c|c|c|}
\hline $\begin{array}{l}\text { Gestational age } \\
\text { (weeks) }\end{array}$ & $\begin{array}{l}\text { Screened infants } \\
\text { (n) }\end{array}$ & Any ROP (n, \%) & Severe ROP $(n, \%)$ \\
\hline$\leq 28$ & 1539 & $968(62.9)$ & $332(21.6)$ \\
\hline $29-32$ & 3425 & $666(19.4)$ & $76(2.2)$ \\
\hline Subtotal $(\leq 32)$ & 4964 & 1634 (32.9) & $409(8.2)$ \\
\hline $33-35$ & 1030 & $56(6.1)$ & $6(0.6)$ \\
\hline$>35$ & 121 & $5(4.1)$ & - \\
\hline Total & 6115 & $1695(27)$ & $414(6.7)$ \\
\hline Birth weight (g) & $\begin{array}{l}\text { Screened infants } \\
\text { (n) }\end{array}$ & Any $\operatorname{ROP}(n, \%)$ & Severe ROP $(n, \%)$ \\
\hline$\leq 1000$ & 1109 & $761(68)$ & $288(26)$ \\
\hline $1001-1250$ & 1085 & $438(40)$ & $74(6.8)$ \\
\hline $1251-1500$ & 1296 & $269(20.8)$ & $33(2.5)$ \\
\hline Subtotal $(\leq 1500)$ & 3490 & $1468(42)$ & 395 (11) \\
\hline $1501-2000$ & 1944 & $201(10.3)$ & $19(1)$ \\
\hline$>2000$ & 681 & $26(3.8)$ & - \\
\hline Total & 6115 & 1695 (27) & $414(6.7)$ \\
\hline
\end{tabular}

ROP, retinopathy of prematurity.

was considered statistically significant. Multiple logistic regression analyses were used to evaluate risk factors for any degree of ROP (BW>1500 g) and severe ROP in infants (BW $\leq 1500 \mathrm{~g}$ ), using the selection of factors associated $(p \leq 0.05)$ with ROP determined by univariate analyses. In the model, no ROP versus severe ROP (BW $\leq 1500 \mathrm{~g}$ ) and no ROP versus any degree of ROP (BW $>1500 \mathrm{~g}$ ) were compared. Variables with a $\mathrm{p} \leq 0.05$ using logistic regression analyses were accepted as independent risk factors. The OR and 95\% CI for each risk factor were determined. The one-way analysis of variance was performed to determine the statistical significance for GA and BW among NICUs in university, state and private hospitals.

\section{RESULTS}

During the study period, data from 69 centres including NICUs of 39 university hospitals (2823 infants), 22 state hospitals (2605 infants) and 8 private hospitals (687 infants) were obtained. All of the participating centres had ophthalmology units for ROP screening, but only 41/69 performed laser photocoagulation and/or antivascular endothelial growth factor (anti-VEGF) treatments and 5/69 centres performed vitreoretinal surgery.

The TR-ROP study included 6115 preterm infants: 4964 (81\%) with a GA $\leq 32$ weeks and 1151 (19\%) with a GA>32 weeks. The mean BW and GA for the total cohort were $1,457 \pm 479 \mathrm{~g}$ and $28.9 \pm 6.3$ weeks, respectively. There were 3163 (51.7\%) females and $2952(48.3 \%)$ males in the study group. The mean postnatal day and postmenstrual age at the initial diagnosis of ROP were $49.2 \pm 16$ days and $33.8 \pm 2.9$ weeks, respectively. Overall, $27 \%$ of the patients were found to have any stage of ROP and $6.7 \%$ had severe ROP. The incidences of ROP and severe ROP in relation to GA and BW are shown in table 1 . The majority (96\%) of infants with any stage of ROP had a GA $\leq 32$ weeks and $80 \%$ of the infants with severe ROP had a GA $\leq 28$ weeks.

Of the total study cohort, a total of 551 infants (9\%) were born to refugees. There were no statistically significant differences in any degree of ROP and severe ROP between very low birth weight (VLBW) infants of citizens $(n=3193)$ and refugees $(\mathrm{n}=297)$.

Univariate analyses identified several risk factors as potential markers. Table 2 shows the relationships between severe ROP and risk factors in infants with a BW $\leq 1500 \mathrm{~g}$. 
Table 2 Univariate analyses of covariates for severe ROP development in infants with a BW $\leq 1500 \mathrm{~g}$

\begin{tabular}{|c|c|c|c|c|c|}
\hline \multirow[b]{2}{*}{ Covariates } & \multicolumn{2}{|l|}{ Infants BW $\leq 1500 \mathrm{~g}$} & \multicolumn{3}{|c|}{$\begin{array}{l}\text { Univariate analysis } \\
\text { (Severe ROP vs No ROP) }\end{array}$} \\
\hline & No ROP $(n=2022)$ & Severe ROP $(n=395)$ & $P$ value & $95 \% \mathrm{Cl}$ & OR \\
\hline Maternal age (years)* & $28.9 \pm 6.4$ & $28.7 \pm 6.2$ & 0.565 & 0.979 to 1.012 & 0.995 \\
\hline Antenatal steroid, two doses & $870(43 \%)$ & $145(36.7 \%)$ & $0.02 \ddagger$ & 0.614 to 0.959 & 0.767 \\
\hline Preeclampsia & $544(26 \%)$ & $83(21 \%)$ & $0.015 \ddagger$ & 0.556 to 0.938 & 0.722 \\
\hline Gestational diabetes & $106(5 \%)$ & $23(5.8 \%)$ & 0.640 & 0.702 to 1.777 & 1.117 \\
\hline Chorioamnionitis & $165(8 \%)$ & $56(14 \%)$ & $<0.001 \ddagger$ & 1.343 to 2.570 & 1.858 \\
\hline IVF pregnancy & $247(12 \%)$ & $41(10 \%)$ & 0.832 & 0.586 to 1.180 & 0.832 \\
\hline \multicolumn{6}{|l|}{ Multiple births } \\
\hline Twins & $424(21 \%)$ & $80(20.3 \%)$ & 0.728 & 0.729 to 1.248 & 0.953 \\
\hline Triplets & $76(3.8 \%)$ & $14(3.5 \%)$ & 0.810 & 0.519 to 1.668 & 0.931 \\
\hline Vaginal delivery & $236(12 \%)$ & $83(21 \%)$ & $<0.001 \ddagger$ & 1.524 to 2.656 & 2.012 \\
\hline Gestational age (weeks)* & $29.8 \pm 2.2$ & $26.5 \pm 1.9$ & $<0.001 \ddagger$ & 0.441 to 0.511 & 0.475 \\
\hline$B W(g)^{*}$ & $1215 \pm 215$ & $888 \pm 228$ & $<0.001 \ddagger$ & 0.994 to 0.995 & 0.994 \\
\hline Male gender & $934(46 \%)$ & $207(52 \%)$ & $0.028 \ddagger$ & 1.035 to 1.593 & 1.284 \\
\hline SGA & $520(25.7 \%)$ & $50(12.7 \%)$ & $<0.001 \ddagger$ & 0.306 to 0.572 & 0.418 \\
\hline Resuscitation at birth & $853(42 \%)$ & $306(77 \%)$ & $<0.001 \ddagger$ & 3.667 to 6.070 & 4.717 \\
\hline RDS & $1228(83 \%)$ & $361(91 \%)$ & $<0.001$ & 4.820 to 9.957 & 6.928 \\
\hline Surfactant treatment & $959(47 \%)$ & $340(86 \%)$ & $<0.001 \ddagger$ & 5.092 to 9.240 & 6.859 \\
\hline Duration of invasive mechanical ventilation (days) $\dagger$ & $0 \pm 2(0-148)$ & $17 \pm 40(0-308)$ & $<0.001 \ddagger$ & 1.063 to 1.080 & 1.071 \\
\hline Duration of noninvasive ventilation (days) $\dagger$ & $3 \pm 7(0-87)$ & $18 \pm 22(0-120)$ & $<0.001 \ddagger$ & 1.079 to 1.100 & 1.090 \\
\hline Total days on oxygent & $10 \pm 23(0-171)$ & $65 \pm 53(0-308)$ & $<0.001 \ddagger$ & 1.047 to 1.057 & 1.052 \\
\hline PDA requiring treatment & $349(36 \%)$ & $210(53 \%)$ & $<0.001 \ddagger$ & 4.326 to 6.837 & 5.438 \\
\hline Intracranial haemorrhage (>Grade II) & $73(3.6 \%)$ & $70(17.7 \%)$ & $<0.001 \ddagger$ & 4.057 to 8.142 & 5.748 \\
\hline Early-onset neonatal sepsis & $433(21 \%)$ & $167(42 \%)$ & $<0.001 \ddagger$ & 2.149 to 3.378 & 2.694 \\
\hline Late-onset neonatal sepsis & $677(33 \%)$ & $294(74 \%)$ & $<0.001 \ddagger$ & 4.537 to 7.394 & 5.792 \\
\hline NEC ( $\geq$ Stage II) & $142(7 \%)$ & $84(21 \%)$ & $<0.001 \ddagger$ & 2.680 to 4.840 & 3.601 \\
\hline BPD & $273(13 \%)$ & $266(67 \%)$ & $<0.001$ & 10.324 to 16.884 & 13.203 \\
\hline \multicolumn{6}{|l|}{ Frequency of RBC transfusions } \\
\hline Once & $426(21 \%)$ & $41(10 \%)$ & $<0.001 \ddagger$ & 2.637 to 7.503 & 4.448 \\
\hline Twice and more & $532(26 \%)$ & $331(83 \%)$ & $<0.001 \ddagger$ & 18.607 to 44.438 & 28.756 \\
\hline $\begin{array}{l}\text { Breastfeeding more than } 80 \% \text { of feeding at PN } 28 \text { days, } \\
(n, \%)\end{array}$ & $1347(66 \%)$ & $162(41 \%)$ & $<0.001 \ddagger$ & 0.279 to 0.434 & 0.348 \\
\hline Age of regain BW (days)* & $11.3 \pm 5.1$ & $14.5 \pm 6$ & $<0.001 \ddagger$ & 1.080 to 1.121 & 1.100 \\
\hline Relative weight gain at 28 days $(\mathrm{g})^{*}$ & $382 \pm 180$ & $229 \pm 135$ & $<0.001 \ddagger$ & 0.993 to 0.995 & 0.994 \\
\hline
\end{tabular}

*The values are presented as mean \pm SD.

tThe values are presented as median \pm IQR, min-max values are given in parentheses.

¥The variables that were put in the logistic regression model.

BPD, bronchopulmonary dysplasia; BW, birth weight; IVF, in vitro fertilisation; $n$, number of patients; NEC, necrotising enterocolitis; $p$, significant difference between patients with severe ROP versus those with no ROP, defined as $\mathrm{p}<0.05$; PDA, patent ductus arteriosus; PN, postnatal; RBC, red blood cell ; RDS, respiratory distress syndrome; ROP, retinopathy of prematurity; SGA, small for gestational age.

All risk factors found to be significant were analysed using a multivariate logistic regression model. Table 3 shows the independent risk factors for severe ROP in VLBW infants.

Using multivariate logistic regression analyses, the following were independent risk factors for any ROP in infants with BW>1500 g: GA (for every $100 \mathrm{~g}$ ) (OR, 0.863; 95\% CI 0.775 to $0.960 ; \mathrm{p}=0.007$ ), BW (for every week) (OR, 0.997; 95\% CI 0.996 to $0.998 ; \mathrm{p}<0.001$ ), RBC transfusion ( $\geq$ once) (OR, 1.545 ; CI 1.067 to $2.237 ; \mathrm{P}=0.021$ ) and total days on oxygen (for each day on oxygen) (OR, 1.023; CI 1.014 to 1.032; $\mathrm{p}<0.001)$.

Of all of the infants screened for ROP, 414 (6.7\%) needed treatment. A total of 395 (95.4\%) of the treated infants had a $\mathrm{BW} \leq 1500 \mathrm{~g}$ and treatment was performed in 19 infants with a BW of 1501-2000 g. Severe ROP was diagnosed in five babies with $\mathrm{BW}>1500 \mathrm{~g}$ and $\mathrm{GA}>32$ weeks who required treatment. Treatment was applied bilaterally in 385 patients and was performed in one eye in 29 cases. Five infants with a GA $\leq 28$ weeks underwent vitreoretinal surgery. Table 4 lists the severities and treatment modalities of ROP in the treated patients.

The incidence of severe ROP in university hospitals, in state hospitals and in private hospitals was $6.2 \%, 6.8 \%$ and $8.4 \%$ respectively. Mean GA and mean BW of infants with severe ROP varied between different types of NICU (table 5).

Appropriate criteria for screening for the NICUs in university hospitals should be $<1700 \mathrm{~g}$ or $\leq 32$ weeks and for the NICUs in state hospitals and private hospitals should be $<1700 \mathrm{~g}$ or $\leq 34$ weeks (figure 1).

\section{DISCUSSION}

ROP is a serious morbidity of prematurity, whose incidence and severity increase with decreasing GA and BW. Studies conducted in high-income countries have shown that infants born at $\geq 32$ 
Table 3 Independent risk factors for severe retinopathy of prematurity in infants with a birth weight $\leq 1500 \mathrm{~g}$

\begin{tabular}{|c|c|c|c|}
\hline & Adjusted OR & $95 \% \mathrm{Cl}$ & $P$ value \\
\hline Gestational age (weeks)* & 0.812 & 0.726 to 0.910 & $<0.001$ \\
\hline Birth weight $(\mathrm{g}) \dagger$ & 0.998 & 0.997 to 0.999 & $<0.001$ \\
\hline Small for gestational age & 0.471 & 0.277 to 0.799 & 0.005 \\
\hline Total days on oxygen $\ddagger$ & 1.025 & 1.019 to 1.031 & $<0.001$ \\
\hline Late-onset sepsis & 1.423 & 1.016 to 1.994 & 0.04 \\
\hline $\begin{array}{l}\text { Frequency of red blood cell } \\
\text { transfusions } \geq \text { twice }\end{array}$ & 2.384 & 1.389 to 4.092 & 0.002 \\
\hline $\begin{array}{l}\text { Relative weight gain at } \\
28 \text { days (grams) }\end{array}$ & 0.998 & 0.997 to 0.999 & $<0.001$ \\
\hline
\end{tabular}

$\mathrm{P}<0.05$ represents statistical significance.

${ }^{*}$ OR for every week.

TOR for every $1 \mathrm{~g}$.

$\ddagger O R$ for each day on oxygen.

weeks are not at risk for developing ROP and most infants born at $>28$ weeks who develop ROP have a mild disease that spontaneously regressed without treatment. ${ }^{9}$ The findings of the TR-ROP study were comparable to those from other developing countries and showed that more mature and heavier babies were at risk for severe ROP. ${ }^{10}$

There were no differences in any ROP and severe ROP development between VLBW infants of refugees and citizens in our study. The Ministry of Health of Turkey has been involved in direct healthcare services in the refugee camps and through the referral of refugees to Turkish hospitals. The 2015 report of the Turkish Neonatology Society reported a mortality rate of

\begin{tabular}{|c|c|c|c|c|}
\hline Severity of ROP & Only IVB & $\begin{array}{l}\text { Only laser } \\
\text { treatment }\end{array}$ & $\begin{array}{l}\text { IVB and laser } \\
\text { treatment }\end{array}$ & $\begin{array}{l}\text { Total N, } \\
(\%)\end{array}$ \\
\hline APROP & 45 & 26 & 15 & $\begin{array}{l}86 \\
(20.8 \%)\end{array}$ \\
\hline Type 1 ROP & 93 & 145 & 24 & $\begin{array}{l}262 \\
(63.3 \%)\end{array}$ \\
\hline $\begin{array}{l}\text { Zone I, any stage of ROP } \\
\text { with plus }\end{array}$ & 28 & 9 & 7 & 44 \\
\hline $\begin{array}{l}\text { Zone I, stage } 3 \text { without } \\
\text { plus }\end{array}$ & 6 & 2 & 2 & 10 \\
\hline $\begin{array}{l}\text { Zone II, stage } 2 \text { or } 3 \\
\text { with plus }\end{array}$ & 59 & 134 & 15 & 208 \\
\hline Type 2 ROP & 20 & 24 & - & $\begin{array}{l}44 \\
(10.6 \%)\end{array}$ \\
\hline $\begin{array}{l}\text { Zone I, stage } 1 \text { or } 2 \\
\text { without plus }\end{array}$ & 4 & 5 & - & 9 \\
\hline $\begin{array}{l}\text { Zone II, stage } 3 \text { without } \\
\text { plus }\end{array}$ & 16 & 19 & - & 35 \\
\hline Unclassified & 6 & 15 & 1 & $\begin{array}{l}22 \\
(5.3 \%)\end{array}$ \\
\hline $\begin{array}{l}\text { Zone II, stage } 1 \text { with } \\
\text { plus }\end{array}$ & 4 & 5 & - & 9 \\
\hline $\begin{array}{l}\text { Zone III, stage } 2 \text { with } \\
\text { plus }\end{array}$ & 1 & 6 & 1 & 8 \\
\hline $\begin{array}{l}\text { Zone III, stage } 3 \text { with } \\
\text { plus }\end{array}$ & 1 & 4 & - & 5 \\
\hline Total N, (\%) & $\begin{array}{l}164 \\
(39.6 \%)\end{array}$ & $\begin{array}{l}210 \\
(50.7 \%)\end{array}$ & $\begin{array}{l}40 \\
(9.7 \%)\end{array}$ & $\begin{array}{l}414 \\
(100 \%)\end{array}$ \\
\hline
\end{tabular}

APROP, aggressive posterior retinopathy of prematurity; IVB, intravitreal bevacizumab; $\mathrm{N}$, number of patients; ROP, retinopathy of prematurity.
Table 5 Mean BWs and GAs of infants with severe ROP according to types of units

\begin{tabular}{lllll}
\hline & $\begin{array}{l}\text { University } \\
\text { hospitals } \\
(\mathbf{n}=192)\end{array}$ & $\begin{array}{l}\text { State } \\
\text { hospitals } \\
(\mathbf{n}=164)\end{array}$ & $\begin{array}{l}\text { Private } \\
\text { hospitals } \\
(\mathbf{n}=58)\end{array}$ & P value* $^{*}$ \\
\hline Mean GA (weeks) & $26.3 \pm 2$ & $26.7 \pm 2.2$ & $27.9 \pm 2.1$ & $<0.05$ \\
\hline Mean BW (g) & $878 \pm 250$ & $905 \pm 273$ & $1128 \pm 299$ & $<0.05$ \\
\hline
\end{tabular}

*The values are significantly higher in private hospitals than in university and state hospitals.

BW, birth weight; GA, gestational age; n, number of patients; ROP, retinopathy of prematurity.

$26 \%$ for babies with a $\mathrm{BW}<1500 \mathrm{~g}$, according to data obtained from 59 NICUs. ${ }^{11}$ However, there were insufficient data on the neonatal mortality of refugees in this report.

GA, BW and oxygen therapy are well-known major risk factors in the development of ROP. ${ }^{12}$ In this study, a lower BW, shorter GA and total days on oxygen were found as independent risk factors for severe ROP in infants with a BW $\leq 1500 \mathrm{~g}$ and for any ROP in infants with a BW $>1500 \mathrm{~g}$.

Some previous studies have reported that the prevalence of ROP was higher in SGA infants compared with appropriate for GA preterms, while SGA was not found to be a risk factor for ROP in other reports. ${ }^{13}{ }^{14}$ Factors that are considered an increased risk for severe ROP in SGA babies include chronic uterine hypoxia, abnormal growth factor levels, nutrient restriction and antioxidant deficiency. ${ }^{15}$ However, in our study, SGA was surprisingly associated with a decreased incidence of severe ROP in VLBW infants when using a multivariate logistic regression model.

There was a relationship between poor postnatal weight gain and an increased risk for ROP. ${ }^{16}$ Poor postnatal weight gain was also found as an independent risk factor for severe ROP in infants with a BW $\leq 1500 \mathrm{~g}$ in our study. Using univariate analyses, several risk factors including RDS, respiratory support, sepsis, NEC, PDA, intracranial haemorrhage and BPD were significantly associated with severe ROP in VLBW infants in our cohort. These perinatal morbidities may have decreased postnatal weight gains.

This study showed that RBC transfusions had strong effects on the development of ROP. Transfusions may increase oxygen delivery to the retina because of the lower oxygen affinity of adult haemoglobin in packed red cells. Repeated transfusions may also cause free iron accumulation, which may result in increased production of free hydroxyl radicals as assessed by the Fenton reaction, resulting in damage to the retina. ${ }^{17}$ Although the role of blood transfusions as a risk factor for ROP was suggested by numerous reports, ${ }^{18} 19$ several studies have reported that a transfusion limitation policy did not reduce the prevalence of ROP. ${ }^{20}$ Our data suggested that limiting blood transfusion in regards to threshold haemoglobin values in guidelines could contribute to reducing the prevalence of ROP.

Multiple studies have reported the role of neonatal sepsis in the development of ROP. ${ }^{2122}$ In this study, late onset sepsis was an independent risk factor for severe ROP in VLBW infants. Sepsis may act through cytokines and endotoxins, which directly affect retinal angiogenesis. This process is frequently accompanied by hypotension, which can cause tissue perfusion impairment and retinal ischaemia. ${ }^{23}$

Treatment was performed in $6.7 \%$ of the infants screened for ROP in the current study. In nearly half of the infants with severe ROP, the treatment modality involved laser photocoagulation and IVB was performed in the other half as the first choice. 

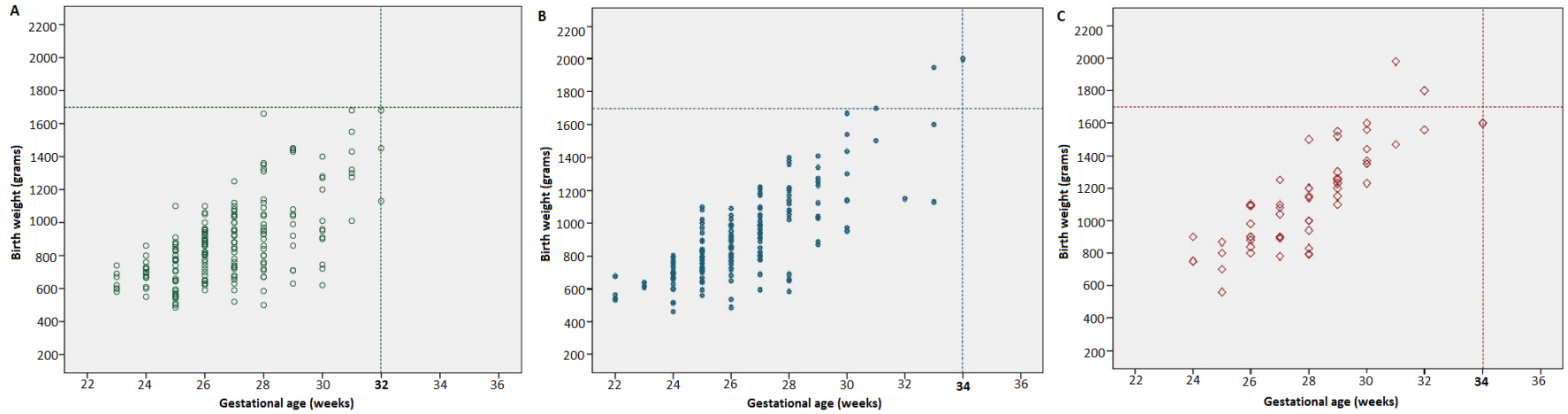

Figure 1 Plots of BW versus GA for infants treated for ROP in three different types of NICU. (A) University hospitals. (B) State hospitals. (C) Private hospitals. BW, birth weight; GA, gestational age; NICU, neonatal intensive care unit; ROP, retinopathy of prematurity.

A nationwide population-based study from the UK reported that diode laser photocoagulation was performed in $90.5 \%$ of infants requiring treatment. ${ }^{1}$ The higher usage of IVB in our study may be due to ease of administration (typically at the bedside). In addition, paediatric anaesthesia for performing laser photocoagulation was not available in some NICUs in our study.

Notably, 66 (16\%) of 414 infants were treated earlier than type 1 ROP and did not fulfil the ETROP requirements for treatment in our study. Twenty-six of these 66 infants were treated with IVB. The popularity of anti-VEGF agents is increasing in Turkey; however, the long-term safety and efficacy of these agents are still not definitively known. The risk of progression to retinal detachment in type 1 ROP is around 15\%, but is much lower with less severe disease. ${ }^{8}$ Evidence-based data are not available to confirm a favourable risk-benefit ratio of IVB usage in cases earlier than type 1 ROP.

In our study, the incidence of severe ROP varied between the three types of NICU which reflects the differences in neonatal care. The rates of severe ROP were lower in university hospital NICUs, where practices for newborn care are likely to be better than non-university NICUs. Based on the results of present study, the screening criteria for ROP need to be wider in state and private hospitals than applied in the university hospitals. ROP programmes in Turkey should adopt the criteria of $<1700 \mathrm{~g}$ or $\leq 34$ weeks to capture all babies requiring treatment.

The strength of the TR-ROP study was that it was a large multicentre cohort study that allowed us to prospectively obtain data via a special network. However, the neonatologists did not go through any training in order to standardise definitions of potential risk factors before the study started. Similarly, the participating ophthalmologists also did not undergo any processes to standardise how they graded ROP. These situations are the limitations of the study.

In conclusion, screening criteria for ROP in Turkey needs to be wider than developed countries. The high incidence of infants with ROP in our study emphasised the need for aggressive measures for prevention and control of the disease. The safe implementation of oxygen therapy with appropriate monitoring, better antenatal and neonatal care, meticulous attention to hygienic procedures and control of sepsis may reduce the prevalence of ROP. Therefore, monitoring standards of neonatal care and conducting quality improvement projects across the country are essential for improving neonatal outcomes in Turkish NICUs.

Correction notice This article has been corrected since it published Online First. Typos in several of the Collaborator names have been corrected.

Acknowledgements We thank Bulent Celik from the Department of Statistics, Gazi University, Ankara, for statistical analysis.
Collaborators TR-ROP Study Group Collaborators (Neonatology): Fatma Nur Sari (Dr Zekai Tahir Burak Women's Health Education and Research Hospital, University of Health Sciences, Ankara); Guner Karatekin (Zeynep Kamil Maternity and Children's Training and Research Hospital, University of Health Sciences, Istanbul); Esad Koklu (Megapark Hospital, Kahramanmaras); Huseyin Altunhan (Necmettin Erbakan University, Meram Faculty of Medicine, Konya); Hatice Turgut (Inonu University Faculty of Medicine, Malatya); Fatma Narter (Kartal Lutfi Kirdar Education and Research Hospital, University of Health Sciences, Istanbul); Nuriye Tarakci (Dr Faruk Sukan Maternity and Children's Hospital, Konya); Kadir Serafettin Tekgunduz (Ataturk University Faculty of Medicine, Erzurum); Servet Ozkiraz (Medicalpark Hospital, Gaziantep): Cumhur Aydemir (Bulent Ecevit University Faculty of Medicine, Zonguldak); Ahmet Ozdemir (Erciyes University Faculty of Medicine, Kayseri); Bilin Cetinkaya (Baskent University Faculty of Medicine, Adana); Ebru Kazanci (Kanuni Sultan Suleyman Training and Research Hospital, University of Health Sciences, Istanbul); Ayhan Tastekin (Medipol University, Istanbul); Sebnem Calkavur (Dr Behcet Uz Children's Hospital, University of Health Sciences, Izmir); Banu Mutlu Ozyurt (Mersin State Hospital, Mersin); Yasar Demirelli (Erzurum Nenehatun Maternity Hospital, Erzurum); Huseyin Selim Asker (NCR International Hospital, Gaziantep); Birgul Mutlu (Doruk Yildirim Private Hospital, Bursa); Ozgun Uygur (Tepecik Training and Research Hospital, University of Health Sciences, Izmir); Hilal Ozkan (Uludag University Faculty of Medicine, Bursa); Didem Armangil (Yuksek Ihtisas University Faculty of Medicine, Ankara); Ferda Ozlu (Cukurova University Faculty of Medicine, Adana); Mustafa Kurthan Mert (Numune Training and Education Hospital, University of Health Sciences, Adana); Hacer Ergin (Pamukkale University Faculty of Medicine, Denizli); Beyza Ozcan (Konya Education and Research Hospital, University of Health Sciences, Konya); Evrim Kiray Bas (Sisli Hamidiye Etfal Education and Research Hospital, University of Health Sciences, Istanbul); Emel Okulu (Ankara University Faculty of Medicine, Ankara); Betul Acunas (Trakya University Faculty of Medicine, Edirne); Ulker Celik (Denizli State Hospital, Denizli); Sait Ilker Uslu (Ondokuz Mayıs University, Faculty of Medicine, Samsun); Mehmet Mutlu (Karadeniz Technical University Faculty of Medicine, Trabzon); Nihat Demir (Yuzuncu Yil University Faculty of Medicine, Van); Funda Eroglu (Ankara Guven Hospital, Ankara); Zeynel Gokmen (Baskent University Faculty of Medicine, Konya): Serdar Beken (Acibadem University Faculty of Medicine, Istanbul); Bilge Tanyeri Bayraktar (Bezmialem University Faculty of Medicine, Istanbul); Nilay Hakan (Mugla Sitki Kocman University Faculty of Medicine, Mugla); Kazım Kucuktasci (Denizli Private Saglik Hospital, Denizli); Aysen Orman (Firat University Faculty of Medicine, Elazig); Serdar Comert (Suleymaniye Maternity, Research \& Training Hospital, University of Health Sciences, Istanbul); Sabahattin Ertugrul (Dicle University Faculty of Medicine, Diyarbakir); Nuran Ustun (Medeniyet University Faculty of Medicine, Istanbul); Ozlem Sahin (Umraniye Education and Research Hospital, University of Health Sciences, Istanbul); Demet Terek (Ege University Faculty of Medicine, Izmir); Yusuf Kale (Cengiz Gokcek Maternity and Children's Hospital, Gaziantep); Murat Konak (Konya Selcuk University Faculty of Medicine, Konya); Sadık Yurttutan (Kahramanmaras Sutcu Imam University Faculty of Medicine, Kahramanmaras); Ozge Aydemir (Osmangazi University Faculty of Medicine, Eskisehir); Aysegul Zenciroglu (Dr Sami Ulus Maternity and Children's Hospital, University of Health Sciences, Ankara); Dilek Sarici (Kecioren Education and Research Hospital, University of Health Sciences, Ankara); Nilufer Guzoglu (Kirikkale University Faculty of Medicine, Kirikkale); Sahin Hamilcikan (Bagcilar Education and Research Hospital, University of Health Sciences, Istanbul); Tugba Gursoy (Koc University Faculty of Medicine, Istanbul); Funda Tuzun (Dokuz Eylul University Faculty of Medicine, Izmir); Rahmi Ors (Medova Hospital, Konya); Selda Arslan (Mustafa Kemal University Faculty of Medicine, Hatay); Arzu Akdag (Bursa Dortcelik Children's Hospital, Bursa); Asli Memisoglu (Marmara University Faculty of Medicine, Istanbul); Beril Yasa (Istanbul University, Istanbul Faculty of Medicine, Istanbul); Berna Hekimoglu (Trabzon Kanuni Education and Research Hospital, University of Health Sciences, Trabzon); Ozden Turan (Baskent University Faculty of Medicine, Ankara); 
Hakan Aylanc (Onsekizmart University Faculty of Medicine, Canakkale); Sahin Takci (Gaziosmanpasa University Faculty of Medicine, Tokat); Tolga Celik (Hacettepe University Faculty of Medicine, Ankara); Suzan Sahin (Adnan Menderes University Faculty of Medicine, Aydin); llknur Kilic (Atasehir Kadikoy Sifa Hospital, Istanbul). TR-ROP Study Group Collaborators (Ophthalmology): Caner Kara (Etlik Zubeyde Hanim Women's Health Teaching and Research Hospital, University of Health Sciences, Ankara); Zuhal Ozen Tunay (Dr Zekai Tahir Burak Women's Health Education and Research Hospital, University of Health Sciences, Ankara); Gokhan Celik (Zeynep Kamil Maternity and Children's Training and Research Hospital, University of Health Sciences, Istanbul); Ibrahim Gozen (Megapark Hospital, Kahramanmaras); Gunhal Satirtav (Necmettin Erbakan University, Meram Faculty of Medicine, Konya); Nihat Polat (Inonu University Faculty of Medicine, Malatya); Ayse Yesim Oral (Kartal Lutfi Kirdar Education and Research Hospital, University of Health Sciences, Istanbul); Mine Tokgoz (Konya Numune Hospital, Konya); Sadullah Keles (Ataturk University Faculty of Medicine, Erzurum); Burak Bilgin (Medicalpark Hospital, Gaziantep); Silay Canturk Ugurbas (Bulent Ecevit University Faculty of Medicine, Zonguldak); Cagatay Karaca (Erciyes University Faculty of Medicine, Kayseri); Nedime Sahinoglu Keskek (Baskent University Faculty of Medicine, Adana); Dilbade Yildiz Ekinci (Kanuni Sultan Suleyman Training and Research Hospital, University of Health Sciences, Istanbul); Ozlem Balci (Istanbul Medipol University, Istanbul); Emir Volkan Altan (Dr Behcet Uz Children's Hospital, University of Health Sciences, Izmir); Sevda Bakbak(Mersin State Hospital, Mersin); Nihan Aksu Ceylan (Erzurum Regional Education and Research Hospital, University of Health Sciences, Erzurum); Sabit Kimyon (Gaziantep University Faculty of Medicine, Gaziantep); Gunay Alyamac (Retina Eye Hospital, Bursa); Gamze Ture (Tepecik Training and Research Hospital, University of Health Sciences, Izmir); Meral Yildiz (Uludag University Faculty of Medicine, Bursa); Feyza Calis (Yuksek Ihtisas University Faculty of Medicine, Ankara); Selcuk Sizmaz (Cukurova University Faculty of Medicine, Adana); Emine Sukgen (Numune Training and Education Hospital, University of Health Sciences, Adana); Ebru Nevin Cetin (Pamukkale University Faculty of Medicine, Denizli); Muammer Ozcimen, (Konya Education and Research Hospital, University of Health Sciences, Konya); Semra Tiryaki Demir (Sisli Hamidiye Etfal Education and Research Hospital, University of Health Sciences, Istanbul); Huban Atila (Ankara University Faculty of Medicine, Ankara); Altan Ozal (Trakya University Faculty of Medicine, Edirne); Gokhan Tufaner (Denizli State Hospital, Denizli); Ozlem Eski Yucel (Ondokuz Mayıs University Faculty of Medicine, Samsun); Mehmet Kola (Karadeniz Technical University Faculty of Medicine, Trabzon); Erbil Seven (Yuzuncu Yil University Faculty of Medicine, Van); Sengul Ozdek (Gazi University Faculty of Medicine, Ankara); Ali Hakan Durukan (Ankara Guven Hospital, Ankara): Ali Kal (Baskent University Faculty of Medicine, Konya); Ali Riza Cenk Celebi (Acibadem University Faculty of Medicine; Istanbul); Ibrahim Arif Koytak (Bezmialem University Faculty of Medicine, Istanbul); Goksu Alacamli (Mugla Sitki Kocman University Faculty of Medicine, Mugla); Arif Esme (Denizli Private Saglik Hospital; Denizli); Onur Catak (Firat University Faculty of Medicine, Elazig); Irfan Perente (Suleymaniye Maternity, Research \& Training Hospital, University of Health Sciences, Istanbul); Alparslan Sahin (Dicle University Faculty of Medicine, Diyarbakir); Aylin Ardagil Akcakaya (Istanbul Medeniyet University Faculty of Medicine Istanbul); Gulunay Kiray (Umraniye Education and Research Hospital, University of Health Sciences, Istanbul); Serhat Nalcaci (Ege University Faculty of Medicine, Izmir); Umit Aksoy (Cengiz Gokcek Maternity and Children's Hospital, Gaziantep); Berker Bakbak (Konya Selcuk University Faculty of Medicine, Konya); Aysegul Comez (Kahramanmaras Sutcu Imam University Faculty of Medicine, Kahramanmaras); Huseyin Gursoy (Osmangazi University Faculty of Medicine, Eskisehir); Emrah Utku Kabatas (Dr Sami Ulus Maternity and Children's Hospital, University of Health Sciences, Ankara); Ikbal Seza Petricli (Etlik Zubeyde Hanim Women's Health Teaching and Research Hospital, University of Health Sciences, Ankara); Mehmet Erhan Yumusak (Kirikkale University Faculty of Medicine, Kirikkale); Ahmet Kirgiz (Bagcilar Education and Research Hospital, University of Health Sciences, Istanbul); Gunay Uludag (Koc University Faculty of Medicine, Istanbul); Aylin Yaman (Dokuz Eylul University Faculty of Medicine, Izmir); Zeynep Dadaci (Medova Hospital, Konya);Ali Karatas (Bursa Dortcelik Children's Hospital, Bursa); Hande Celiker (Marmara University Faculty of Medicine, Istanbul);Zafer Cebeci (Istanbul University, Istanbul Faculty of Medicine, Istanbul); Mahmut Cenap Esenulku (Trabzon Kanuni Education and Research Hospital, University of Health Sciences, Trabzon); Imren Akkoyun (Baskent University, Faculty of Medicine, Ankara); Ismail Ersan (Onsekizmart University Faculty of Medicine, Canakkale); Selim Demir (Gaziosmanpasa University Faculty of Medicine, Tokat); Sibel Kadayifcilar (Hacettepe University Faculty of Medicine, Ankara); Ayse Ipek Akyuz Unsal (Adnan Menderes University Faculty of Medicine, Aydin); Mumin Hocaoglu (Istanbul Retina Institute, Istanbul).

Contributors All authors made substantial contributions to conception, design, analysis and interpretation of data and contributed to writing the article and approved the current version.

Funding This research received no specific grant from any funding agency in the public, commercial or not-for-profit sectors
Competing interests None declared.

Patient consent Guardian consent obtained.

Ethics approval The study was approved by the ethical review committee of Gulhane Faculty of Medicine.

Provenance and peer review Not commissioned; externally peer reviewed.

Open access This is an open access article distributed in accordance with the Creative Commons Attribution Non Commercial (CC BY-NC 4.0) license, which permits others to distribute, remix, adapt, build upon this work non-commercially, and license their derivative works on different terms, provided the original work is properly cited and the use is non-commercial. See: http://creativecommons.org/ licenses/by-nc/4.0/

(c) Article author(s) (or their employer(s) unless otherwise stated in the text of the article) 2018. All rights reserved. No commercial use is permitted unless otherwise expressly granted.

\section{REFERENCES}

1 Adams GGW, Bunce C, Xing W, et al. Treatment trends for retinopathy of prematurity in the UK. BMJ Open 2017;21:7.

2 Gilbert C. Retinopathy of prematurity: a global perspective of the epidemics, population of babies at risk and implications for control. Early Hum Dev 2008;84:77-82.

3 Chaudhry TA, Hashmi FK, Salat MS, et al. Retinopathy of prematurity: an evaluation of existing screening criteria in Pakistan. Br J Ophthalmol 2014;98:298-301.

4 Mikolajczyk RT, Zhang J, Betran AP, et al. A global reference for fetal-weight and birthweight percentiles. Lancet 2011;377:1855-61.

5 Papile LA, Burstein J, Burstein R, et al. Incidence and evolution of subependymal and intraventricular hemorrhage: a study of infants with birth weights less than 1,500 gm. J Pediatr 1978;92:529-34.

6 Bell MJ, Ternberg JL, Feigin RD, et al. Neonatal necrotizing enterocolitis. Therapeutic decisions based upon clinical staging. Ann Surg 1978;187:1-7.

7 International Committee for the Classification of Retinopathy of Prematurity. The International Classification of Retinopathy of Prematurity revisited. Arch Ophthalmol 2005;123:991-9.

8 Early Treatment For Retinopathy Of Prematurity Cooperative Group. Revised indications for the treatment of retinopathy of prematurity: results of the early treatment for retinopathy of prematurity randomized trial. Arch Ophthalmol 2003;121:1684-9.

9 Holmström G, Hellström A, Jakobsson P, et al. Evaluation of new guidelines for ROP screening in Sweden using SWEDROP - a national quality register. Acta Ophthalmol 2015;93:265-8.

10 Tabarez-Carvajal AC, Montes-Cantillo M, Unkrich KH, et al. Retinopathy of prematurity: screening and treatment in Costa Rica. Br J Ophthalmol 2017;101:1709-13.

11 Society TN. Mortality rates in Turkish NICUs in 2016. Turk Neonatol Soc Bull 2017;29:32-4. Article in Turkish.

12 Phelps DL. Retinopathy of prematurity. In: Martin RJ, Fanaroff AA, Walsh MC, eds. Fanaroff and Martin's neonatal perinatal medicine: diseases of the fetus and infant. Philadelphia: Elsevier Saunders, 2015:1767-74.

13 Bernstein IM, Horbar JD, Badger GJ, et al. Morbidity and mortality among very-lowbirth-weight neonates with intrauterine growth restriction. The vermont Oxford Network. Am J Obstet Gynecol 2000;182:198-206.

14 Filho JBF, Valiatti FB, Eckert GU, et al. Is being small for gestational age a risk factor for retinopathy of prematurity? A study with 345 very low birth weight preterm infants. J Pediatr 2009;85:48-54.

15 Kavurt S, Özcan B, Aydemir O, et al. Risk of retinopathy of prematurity in small for gestational age premature infants. Indian Pediatr 2014;51:804-6.

16 Hellström A, Hård AL, Engström E, et al. Early weight gain predicts retinopathy in preterm infants: new, simple, efficient approach to screening. Pediatrics 2009;123:e638-e645.

17 Wardle SP, et al. Effect of blood transfusion on lipid peroxidation in preterm infants. Arch Dis Child Fetal Neonatal Ed 2002:86:46F-8.

18 Hesse L, Eberl W, Schlaud M, et al. Blood transfusion. Iron load and retinopathy of prematurity. Eur J Pediatr 1997:156:465-70.

19 Dani C, Reali MF, Bertini G, et al. The role of blood transfusions and iron intake on retinopathy of prematurity. Early Hum Dev 2001;62:57-63.

20 Kirpalani H, Whyte RK, Andersen C, et al. The Premature Infants in Need of Transfusion (PINT) study: a randomized, controlled trial of a restrictive (low) versus liberal (high) transfusion threshold for extremely low birth weight infants. J Pediatr 2006;149:301-7.

21 Tolsma KW, Allred EN, Chen ML, et al. Neonatal bacteremia and retinopathy of prematurity: the ELGAN study. Arch Ophthalmol 2011;129:155-63.

22 Stoll BJ, Hansen NI, Adams-Chapman I, et al. Neurodevelopmental and growth impairment among extremely low-birth-weight infants with neonatal infection. JAMA 2004; 292:2357-65.

23 Lee J, Dammann 0. Perinatal infection, inflammation, and retinopathy of prematurity. Semin Fetal Neonatal Med 2012;17:26-9. 